\title{
The Role of Research and Innovation in Europe for the Decarbonisation of Waterborne Transport
}

\author{
Monica Grosso*(D), Fabio Luis Marques dos Santos (D), Konstantinos Gkoumas (D), Marcin Stępniak \\ and Ferenc Pekár (D)
}

Citation: Grosso, M.; Marques dos Santos, F.L.; Gkoumas, K.; Stępniak, M.; Pekár, F. The Role of Research and Innovation in Europe for the Decarbonisation of Waterborne Transport. Sustainability 2021, 13, 10447. https://doi.org/10.3390/ su131810447

Academic Editor: Marco Raugei

Received: 6 July 2021

Accepted: 10 September 2021

Published: 19 September 2021

Publisher's Note: MDPI stays neutral with regard to jurisdictional claims in published maps and institutional affiliations.

Copyright: (c) 2021 by the authors. Licensee MDPI, Basel, Switzerland. This article is an open access article distributed under the terms and conditions of the Creative Commons Attribution (CC BY) license (https:// creativecommons.org/licenses/by/ $4.0 /)$.
Joint Research Centre (JRC), European Commission, 21027 Ispra, Italy; fabio.marques-dos-santos@ec.europa.eu (F.L.M.d.S.); konstantinos.gkoumas@ec.europa.eu (K.G.); marcin.stepniak@ec.europa.eu (M.S.); ferenc.pekar@ec.europa.eu (F.P.)

* Correspondence: monica.grosso@ec.europa.eu; Tel.: +39-0332-785-847

Abstract: Waterborne transport contributes to around 14\% of the overall greenhouse gas emissions of transport in the European Union and it is among the most efficient modes of transport. Nonetheless, considering the aim of making the European Union carbon-neutral by 2050 and the fundamental role of waterborne transport within the European economy, effort is needed to reduce its environmental impact. This paper provides an assessment of research and innovation measures aiming at decreasing waterborne transport's $\mathrm{CO}_{2}$ emissions by assessing European projects based on the European Commission's Transport Research and Innovation Monitoring and Information System (TRIMIS). Additionally, it provides an outlook of the evolution of scientific publications and intellectual property activity in the area. The review of project findings suggests that there is no single measure which can be considered as a problem solver in the area of the reduction of waterborne $\mathrm{CO}_{2}$ emissions, and only the combination of different innovations should enable reaching this goal. The highlighted potential innovations include further development of lightweight composite materials, innovative hull repair methods, wind assisted propulsion, engine efficiency, waste heat electrification, hydrogen and alternative fuels. The assessment shows prevalence of funding allocated to technological measures; however, non-technological ones, like improved vessel navigation and allocation systems, also show a great potential for the reduction of $\mathrm{CO}_{2}$ emissions and reduction of negative environmental impacts of waterborne transport.

Keywords: waterborne decarbonisation; research and innovation; technical measures; operational measures; coordination and support measures

\section{Introduction}

Waterborne transport includes maritime and inland waterways transport. This transport mode represents more than $80 \%$ of global freight volume, as 11 billion tons of freight were transported on water in 2018. Nevertheless, in the same year the annual growth of international maritime transport slowed down, with an increase of $2.7 \%$, which is somewhat below the historical average of 3.0\% from 1970-2017 and 4.1\% in 2017. This was in line with a global trade slowdown in 2018 [1]. The role of this sector in Europe's economy is significant, as maritime transport represents $70.1 \%$ of the European Union's (EU) external freight trade by weight and $29.2 \%$ of intra-EU traffic. Additionally, inland waterways accounted for $3.9 \%$ of the total goods transport in the 27 EU Member States (EU-27) in 2018 [2]. In terms of employment, the waterborne transport sector employed almost 400,000 people and accounts for more than EUR 35,000 million of GDP [3].

Waterborne transport is among the least carbon intensive modes of transport in terms of $\mathrm{CO}_{2}$ per ton $\mathrm{km}$ transported. Nevertheless, the International Maritime Organisation's (IMO) estimated that international shipping produced around 1 billion tons of $\mathrm{CO}_{2}$, representing about $2.8 \%$ of total man-made emissions in 2018. Moreover, the growth of transport 
demand is expected to continue [4]. As a consequence, those emissions could increase by up to $50 \%$ until 2050 compared to 2018 levels, despite further efficiency gains.

Waterborne transport represents $14.1 \%$ of greenhouse gas (GHG) emissions produced by the European transport sector in 2018 [2], which is slightly more than European aviation $(13.2 \%)$. Considering its fundamental importance to the European economy and its global nature, effort is needed to reduce its environmental impact $[5,6]$. To date, EU legislation and international agreements have focused on pollution reductions; however, emphasis on reducing GHG emissions has substantially increased recently, in line with the objectives of the European Green Deal [7].

At the international level, IMO rules are addressed within the International Convention for the Prevention of Pollution from Ships (MARPOL). The Annex VI refers to the following aspects: accidental and operational oil pollution, noxious liquid substances in bulk pollution, pollution by harmful substances carried in packaged forms, sewage, garbage, air pollution and efficiency via the EEDI (Energy Efficiency Design Index) and SEEMP (Ship energy efficiency management plan).

In Europe, the actions defined in the European Green Deal pursue the objective of obtaining a sustainable European economy, where no net GHG emissions will be present, by 2050 . This includes a $90 \%$ reduction in emissions from European transport. The recent Strategy for a Sustainable and Smart Mobility set the pathway to reach a European transport system which should be sustainable, smart and resilient by 2050 [8]. The EU's strategy towards reducing GHG emissions in the shipping industry [9] foresees a three step approach. Moreover, it includes a list of key measures, such as the implementation of a monitoring, reporting and verification (MRV) system, the definition of GHG reduction targets for maritime transport and the implementation of market-based measures.

Scientific literature and business cases report a wide range of measures, either already applied or in research phases that could enable maritime transport to become less polluting. A list of 22 measures have been identified in [10], which fall within the following categories: hull design, power and propulsion, alternative fuels, alternative energy sources and operations. The detail review of previous research on the topic provides estimations of possible $\mathrm{CO}_{2}$ reduction for each measure, concluding that significant emission reductions could be achieved by the quick adoption and combination of different measures. Effective regulatory frameworks have been included in the list of $\mathrm{CO}_{2}$ emissions control measures in [11] which details technological and commercial features of the identified measures and concludes on their interdependent impacts. In [12], four possible estimations of shipping decarbonisation have been presented estimating $\mathrm{CO}_{2}$ reductions ranging from $82 \%$ to $95 \%$ by 2035 , emphasising the role of alternative fuels and renewable energy together with the support of operational measures.

The actions aiming at reducing waterborne transport emissions vary from promoting technological solutions to operational measures and support and coordination actions [11,12]. A range of technologies for reducing emissions from waterborne transport either has been implemented in vessel fleets or is currently under development. At the vessel level, naval architects have developed and refined design techniques for ships to improve the overall hydrodynamic shape to reduce resistance and hence reduce the power required to cruise at a given speed. A further refinement has been introduced in recent years to tailor ship designs to a lower design speed aiming for efficiency increases, mainly as an impact of the EEDI on the ship speed design, which could range from $1.5 \%$ to $10 \%$ of speed differences, depending on the vessel types $[13,14]$. The use of lighter materials in some parts of the ship construction also contribute to reduced resistance [15]. On the engine side, the vast majority of ships use large diesel engines of either the two-stroke or four-stroke mode running on heavy fuel oil (HFO). Their design has also evolved over time, incorporating enhancements such as the Miller cycle [16], two-stage turbocharging and advanced fuel injection systems [15]. These technologies are already widely implemented in new ship engines. More recently, engine manufacturers have begun to produce engines designed to run on both HFO and natural gas (usually stored as Liquified Natural Gas (LNG)). 
However, the appropriate engine technologies to maximise GHG reductions may not be economically profitable, and policies or regulations should account for this fact [17].

More advanced ship propulsion technologies that are under development include wind propulsion devices such as Flettner rotors [18] and other wind-assisted ship propulsion (WASP) systems such as wind turbines and sails. The energy savings deriving from WASP may vary based on the technologies specifications and ships type, nonetheless showing significant potential in fuel reductions based on the different technologies used: rotors: $0.4-50 \%$, kites: $1-50 \%$, rigid sails: $5-60 \%$, soft sails: $4.2-35 \%$ and wind turbines: $1-4 \%$ [19].

There has been considerable interest in the use of alternative fuels for shipping [20], in particular LNG, hydrogen and ammonia [21]. Nevertheless, maritime transport (and aviation) are not expected to be supplied with a significant amount of biofuels in the near future, and the current set of measures is not perceived as sufficient to support waterborne decarbonisation through biofuels [22].

The fuel consumption of a ship is strongly related to the speed at which the ship cruises. The cruising speed depends on a number of factors, principally the income for the operator and fuel costs. There is effectively (at least) a cubic relationship between the speed of a ship and the power required to propel it, thus a higher speed can increase fuel costs significantly [23]. For example, a $10 \%$ reduction in speed leads to a $27 \%$ decrease in power demand. Accounting for the lower distance covered, a 10\% speed reduction results in a $19 \%$ reduction in fuel consumption per unit distance. Such reduction in fuel consumption also leads to similar reduction in $\mathrm{CO}_{2}$ emissions, which depending on the vessel types could be from $10 \%$ to $38 \%$ if the ships reduce their speed by $10 \%$ to $30 \%[24,25]$.

Another factor that influences a ship's fuel consumption and hence emissions is route planning. A route that avoids poor weather, including adverse winds, may lead to lower fuel consumption than one that is theoretically shorter but encounters adverse conditions. Improved route planning technologies, taking advantage of improvements in weather forecasting capabilities, can help the ships' captains to plan optimised routes to follow. Such an operational measure could lead to a possible reduction of $\mathrm{CO}_{2}$, estimated to be between $0.10 \%$ and $3.7 \%$ of the total emissions [15]. When berthed in ports, ships generally use their on-board auxiliary engines to provide power to run the ship's system, including heating and air conditioning. The use of cold ironing to replace the use of the auxiliary engines means significant reductions in pollutant emissions.

To ensure that targeted emissions reductions are achieved on a 'net' basis, some sectors have introduced market based measures such as emissions trading or offsetting [26]. For example, in aviation, intra-EU flights have been subject to the EU Emissions Trading System (EU ETS) since 2012, while a new global measure, the International Civil Aviation Organisation (ICAO) Carbon Offsetting and Reduction Scheme for International AviationCORSIA [27] will be introduced starting in 2021. To date, no such schemes have been introduced for maritime transport. However, Directive (EU)2018/410 [28] notes that all sectors of the economy should contribute to the reduction of greenhouse gas emissions and the European Commission (EC) announced in the Strategy for a Sustainable and Smart Mobility [8] that it will propose the extension of EU ETS to the maritime transport sector; moreover, the EU Strategy aims to achieve the target of zero emission vessels and to increase the share of inland waterways and short sea shipping by $25 \%$ by 2030 and by $50 \%$ by 2050 . The EU introduced a requirement for all large ships entering EU ports to report their emissions via a MRV scheme [29] known as THETIS-MRV [30]. This scheme was seen as a first step in a staged approach to the inclusion of maritime emissions in the EU's GHG reduction commitment [31].

As previously stated, the EU is taking actions aiming to reduce waterborne transport emissions in many areas. The EU has a key role to play through regulatory actions, but also through financial incentives and the promotion of Research and Innovation (R\&I) to develop or enhance innovative technologies. The European Green Deal identifies R\&I as a 
key aspect for increasing European competitiveness where the transport sector represents one of the most important European industries, both in economic and R\&I terms.

R\&I can boost technological innovation and help with achieving the emissions targets set at the European level. For this reason, in May 2017 EC adopted the Strategic Transport Research and Innovation Agenda (STRIA), as part of the 'Europe on the Move' package. STRIA highlights main transport R\&I areas and priorities for clean, connected and competitive mobility [32]. The EC Joint Research Centre (JRC) has developed the Transport Research and Innovation Monitoring and Information System (TRIMIS) to support the implementation of STRIA and monitor technology trends and transport R\&I capacities, as detailed further in the methodological description.

This paper uses the TRIMIS database and capabilities [33], co-developed by the authors, in order to review recent developments, measures and research trends related to waterborne transport, focusing on those related to reduction of $\mathrm{CO}_{2}$ emissions. The aim of the paper is:

- to provide an overview of waterborne transport projects focusing on decarbonisation, financed through the latest European Framework Programmes (FPs) for research and innovation through a quantitative assessment;

- to qualitatively assess the related project's technologies and measures in the areas of control and reduction of waterborne $\mathrm{CO}_{2}$ emissions; and,

- to identify research gaps which will help with providing relevant recommendations for future research and policy developments.

The rest of the paper is organised as follows. Section 2 presents the methodological framework of this work. Section 3 presents the quantitative and qualitative assessment of projects in the TRIMIS database. Section 4 provides discussions and conclusive remarks.

\section{Material and Methods}

The methodological approach used for this analysis combines two complementary parts. First, a quantitative overview of EU projects dealing with waterborne decarbonisation is presented, supplemented by the analysis of evolution of peer reviewed scientific publications and patents associated to those technologies. The second part contains a qualitative assessment of EU projects which aims to identify main R\&I directions and technologies. This analysis helped define future indication both at research and policy levels.

This analysis uses the TRIMIS database [34] which contains nearly 9000 publicly available transport research projects and focuses on the most recent FPs, i.e., the 7th Framework Program for Research (FP7) and the Horizon 2020 Framework Program for Research and Innovation (H2020). Projects funded under previous or other R\&I programmes like CEF or LIFE, as well as those funded through national research programmes were excluded, as their results are potentially outdated or their description in the database was not complete. The TRIMIS database includes projects' mode categorisation, which permits identifying all waterborne transport projects. Multimodal projects directly linked to waterborne transport were also added to the selection. Finally, the full list contains detailed data on 205 research projects.

The next step of analysis uses a keyword search to identify projects related to decarbonisation of waterborne transport. The selected keywords are decarbonisation, $\mathrm{CO}_{2}$ and emission and the search covers descriptive text reported in the project objectives, background, methodology and key results. The search was followed by a manual check to verify the accuracy of the selection. The process led to a final selection of 133 projects (for the full list of selected projects, see [35]).

The final step of projects identification and categorisation is based on a literature review $[6,10,12,36,37]$. It leads to the definition of 5 sub-themes:

1. Hull design which includes projects focusing on lightweight composite materials for structural components, innovative hull repair methods and hull surface protection; 
2. Power and propulsion which covers projects focusing on wind assisted propulsion, increases in engine efficiency and recycling of waste heat for use elsewhere in the vessel;

3. Fuels and alternative energy sources which covers projects focusing on the use of electrification (batteries, hybrid systems), use of hydrogen, LNG or compressed natural gas (CNG) or liquefied petroleum gas (LPG) as a fuel;

4. Operational measures which identifies projects focusing on topics such as improved vessel navigation, vessel allocation systems and robotic container handling systems;

5. Coordination and support measures, including research, networking activities: which covers projects focusing on the dissemination and consolidation of research in the waterborne transport sector, as well as planning and investigating future strategy for the sector, including both vessel and port design.

The first three sub-themes (i.e., hull design, power and propulsion and fuels and alternative energy sources) are directly related to a technological advancement, while the other two sub-themes cover other type of measures within the waterborne transport sector. It should be noted that projects may be relevant to multiple sub-themes or can investigate technologies and measures which are not constrained to just one sub-theme. Therefore, projects can be classified under more than one sub-theme.

Then, manual categorisation of the projects was carried out, supported by machine learning and natural language processing methodologies. For this purpose, the Gensim python library [38] was used. Text summaries and keywords were extracted using automated text summarisation and keyword extraction methods [39] on the full project text corpus available from the projects in TRIMIS. Projects were then manually categorised based on the summaries and keywords.

An analysis of the evolution of peer reviewed scientific publications and patents associated with waterborne research complements the quantitative part of the study. The former focuses on the main trends in waterborne research and locates results in the broader, international context, while the latter aims to provide additional insights into private investments and research outputs related to technological topics. The Scopus citation database of data on journal and conference publications [40] is used, limited to the period 2010-2019. A list of regular expressions (REGEX) used for the extraction and categorization of publications is presented in the Appendix A. The patent analysis is based on the European Patent's Office (EPO) Worldwide Patent Statistical Database (PATSTAT). The search was carried out using cooperative patent classification (CPC) codes, patent titles and abstracts. The search was restricted to the CPC code "B63-SHIPS OR OTHER WATERBORNE VESSELS; RELATED EQUIPMENT", and it covers the period of 5 years (2013 to 2017). This time restriction was necessary since the time lap between patent application and granting is generally relatively long; thus, 2017 was the last year on which a meaningful number of granted patents was available in this area.

The final step of the quantitative assessment refers to the maturity of technology researched within specific projects, focusing on technologies developed within the first three technology-oriented subthemes. The assessment aims to understand the extent to which a certain technology is market ready by categorising technology maturity in four phases (research, validation, demonstration and implementation) [41], in a similar way to the original technology readiness levels (TRLs) used by the National Aeronautics and Space Administration (NASA) [42].

For the qualitative analysis, a selection from the 133 identified projects was used, categorised under each sub-theme in order to identify the overall direction of the respective research progress [35]. These projects were selected based on the overall scale of the project (i.e., total funding value), the availability of results and conclusions on the research being performed. Table 1 shows projects examined in detail to illustrate the progress being achieved in particular topics. 
Table 1. List of the projects included in the qualitative assessment.

\begin{tabular}{|c|c|c|c|c|}
\hline Subtheme & Project Acronym & Key Themes & $\begin{array}{l}\text { Funding } \\
\text { Programme }\end{array}$ & Duration \\
\hline \multirow{6}{*}{ Hull design } & ADAM4EVE & $\begin{array}{l}\text { Adaptive hull structures; } \\
\text { smart materials }\end{array}$ & FP7-TRANSPORT & 2013-2015 \\
\hline & HILDA & Friction stir welding & FP7-TRANSPORT & 2012-2015 \\
\hline & LEAF & Hull surface antifouling technology & FP7-TRANSPORT & 2012-2015 \\
\hline & MOSAIC & High-strength low-alloy steels & FP7-TRANSPORT & 2012-2015 \\
\hline & FIBRESHIP & Fibre reinforce polymers & $\mathrm{H} 2020$ & 2017-2020 \\
\hline & COMPA 2GO & Smart repair service & H2020 & 2018-2020 \\
\hline \multirow{6}{*}{$\begin{array}{l}\text { Power and } \\
\text { propulsion }\end{array}$} & RotorDEMO & Wind assisted propulsion & H2020 & 2017-2018 \\
\hline & GFF & Fully electric ferry & H2020 & 2016-2018 \\
\hline & EEECSM-2 & Waste heat to energy & H2020 & 2016-2018 \\
\hline & LeanShips & $\begin{array}{c}\text { Increased engine efficiency, emissions abatement } \\
\text { technologies }\end{array}$ & H2020 & 2015-2019 \\
\hline & HERCULES-2 & Increased engine efficiency, fuel-flexible engines & H2020 & 2015-2018 \\
\hline & RotorDEMO & Wind assisted propulsion & H2020 & $2017-2018$ \\
\hline \multirow{5}{*}{$\begin{array}{c}\text { Fuels and } \\
\text { alternative } \\
\text { energy sources }\end{array}$} & BB Green & Vessel electrification; reduced hull resistance & FP7-TRANSPORT & 2011-2014 \\
\hline & PURE & Fuel-cell auxiliary power unit & FP7-JTI & 2013-2016 \\
\hline & E-ferry & Fully-electric ferry & H2020 & 2015-2019 \\
\hline & MARANDA & Hybrid fuel-cell powertrain system & H2020 & 2017-2021 \\
\hline & HyMethShip & Hydrogen-methanol propulsion system & H2020 & 2018-2021 \\
\hline \multirow{6}{*}{$\begin{array}{l}\text { Operational } \\
\text { measures }\end{array}$} & RCMS & Robotic container management system & H2020 & 2015-2017 \\
\hline & CLOUD-VAS & Cloud-based vessel allocation & H2020 & 2015-2017 \\
\hline & LOGIMATIC & $\begin{array}{l}\text { Global Navigation Satellite Systems (GNSS); route } \\
\text { planning }\end{array}$ & H2020 & 2016-2019 \\
\hline & SHIPLYS & Virtual prototyping, life-cycle assessment & H2020 & 2016-2019 \\
\hline & $\mathrm{H} 2 \mathrm{H}$ & Safe vessel navigation & H2020 & 2017-2020 \\
\hline & AUTOSHIP & Autonomous vessels & H2020 & $2019-2022$ \\
\hline \multirow{5}{*}{$\begin{array}{l}\text { Coordination } \\
\text { and support } \\
\text { measures }\end{array}$} & MESA & Dissemination of research & FP7-TRANSPORT & 2013-2016 \\
\hline & VDRConnect & Market assessment of technology & $\mathrm{H} 2020$ & 2016-2016 \\
\hline & Prominent & Assessment of technology development areas & H2020 & 2015-2018 \\
\hline & DocksTheFuture & $\begin{array}{c}\text { Port technology standardisation, dissemination, } \\
\text { networking }\end{array}$ & H2020 & 2018-2020 \\
\hline & MarTERA & Coordination of technologies & H2020 & 2016-2021 \\
\hline
\end{tabular}

Source: Adapted from data available in [35].

Figure 1 shows a diagram with the steps taken to perform the analyses in the methodology. Since full information on the achievements of the projects is not available until the publication of the final report, the majority of projects considered in detail are those that have been already completed. Nonetheless, some projects which have not yet been fully completed are also included in the assessment, motivated by the availability of data and their proposed innovative solutions. 


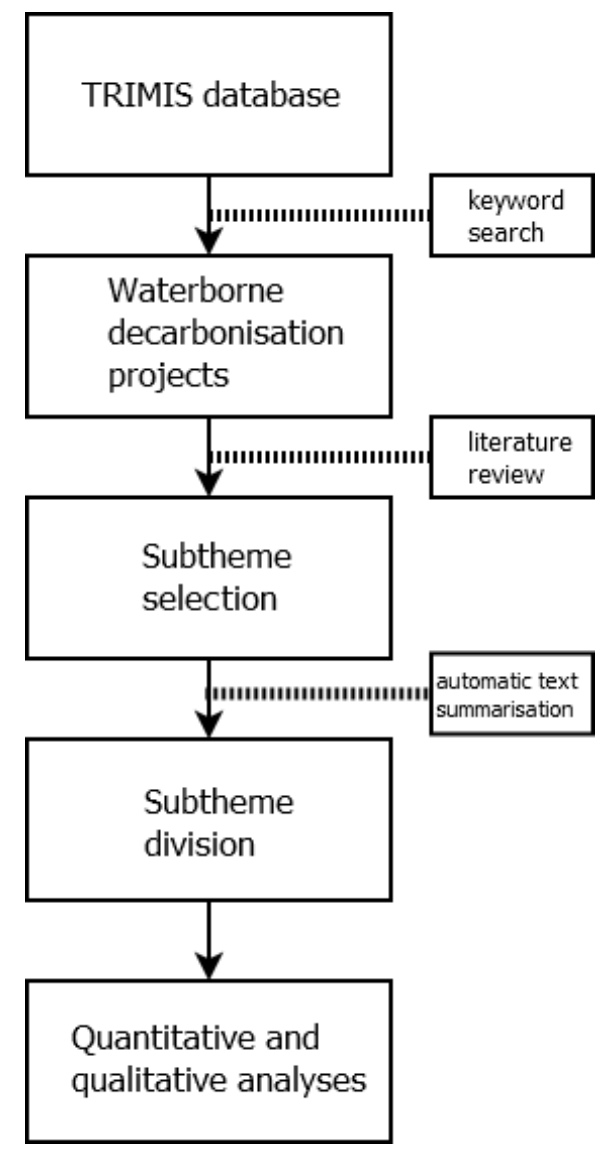

Figure 1. Diagram summarising the methodology.

\section{Results}

\subsection{Quantitative Assessment}

Figure 2 shows the total number of projects touching upon the decarbonisation topic and the division in sub-themes. Approximately $65 \%$ of the waterborne projects deal with decarbonisation. The majority of decarbonisation-related projects are technical-oriented, while a significantly lower and similar number of them focus on operational issues as well as on coordination and support measures. It is important to note that the total number of projects within all the subcategories is greater than the number of decarbonisation projects, because some projects are double labelled (e.g., technical and coordination and support measures).

In total, under FP7 and H2020, around EUR 995 million has been invested and are currently being spent in waterborne transport decarbonisation research projects. These values include estimates for the years 2021-2023 which are based on the expected project costs.

Figure $3 \mathrm{~A}$ shows the evolution of the waterborne and decarbonisation transport projects costs from 2008 to 2020, including costs for each decarbonisation subtheme. The project costs are calculated by dividing the total project budget by its duration and assigning them to the respective years. There are two peaks of invested money in the years 2012 and 2018. They are related to peaks of activities within both analysed framework programmes (2012 for FP7 and 2018 for H2020). 


\section{Decarbonisation projects}

Technical

Operational

Coordination and support and support
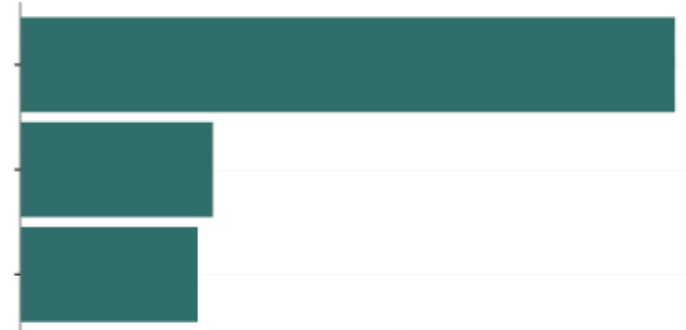

50 100

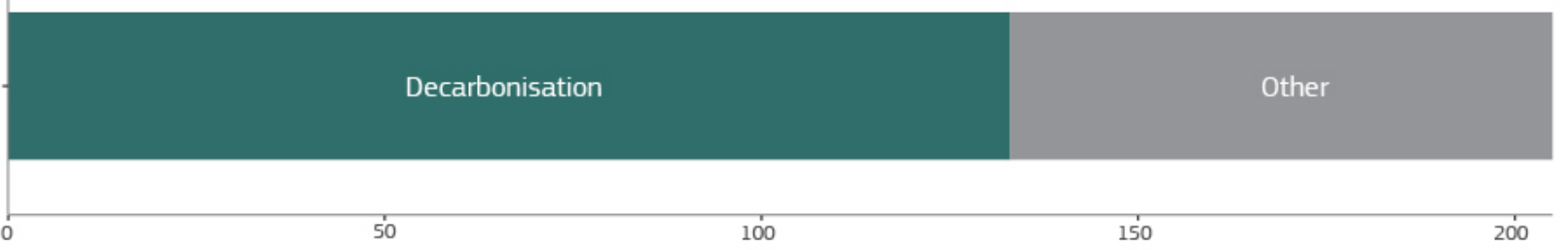

Figure 2. Waterborne projects and theme division. Reprinted from ref. [35].

\section{A}

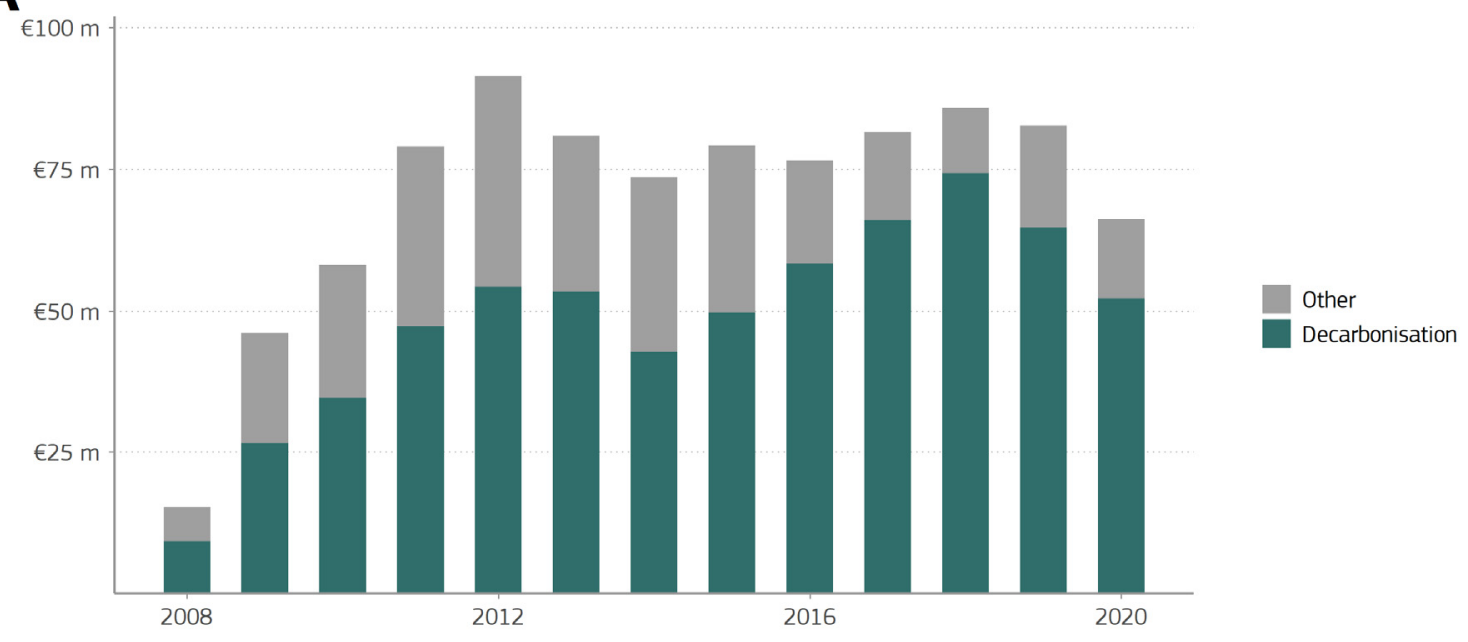

B

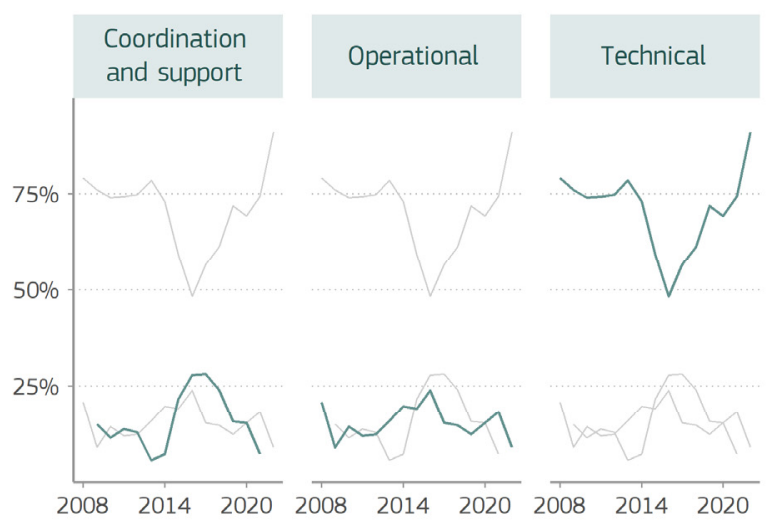

\section{C}

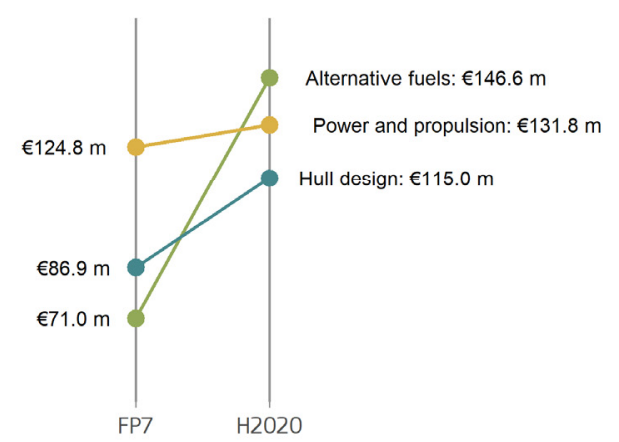

Figure 3. Waterborne project costs in the period 2008 to 2020. (A) Waterborne and decarbonisation waterborne project costs; (B) Yearly decarbonisation project costs by theme; (C) Total technical decarbonisation project costs under FP7 and H2020. Note these costs do not sum to $100 \%$ of cost, as they include overlap with other sub-themes. Source: Adapted from data available in [35]. 
Further, the share of decarbonisation waterborne transport projects increased substantially during the duration of H2020 programme. EUR 71 million out of a total waterborne budget of EUR 464 million has been spent on decarbonisation projects. This is in line with the evolution of the number of decarbonisation projects within waterborne research. The FP7 programme funded 102 waterborne transport projects, of which 53 are under the decarbonisation theme, while in case of H2020, these numbers are 103 and 80, respectively. An increase of share of decarbonisation-related projects in waterborne transport research from 52\% in FP7 to nearly 78\% in H2020. This clearly shows an increased importance of decarbonisation in research activities.

Figure 3B shows the evolution of funding distribution split into three main categories, namely technical, operational measures and coordination and support measures. In general, the chart reveals a similar pattern to the one presented by the Figure 2, as most of the funding, from $50 \%$ up to $80 \%$, supports technical-focused projects. The latter two categories attract a similar share of funding. Moreover, this general pattern is relatively stable over the course of the analysed period of time.

Figure 3C provides further details regarding main trends of investments in waterborne research, limiting the data to the three, technical oriented sub-themes. In the hull design sub-theme, there are similar proportions of participation in both FPs, power and propulsion shows a decrease in budget for H2020, while fuels and alternate energy sources present an increase in project funding in H2020. It could be concluded that there is a budget shift between the two well-linked topics, with fuels and alternate energy sources being the prevalent one in $\mathrm{H} 2020$.

Table 2 presents a summary of the total number of projects implemented during both framework programmes, their total funding and EU contribution. The technical projects are more numerous and received higher funding during the last two R\&I financial framework. The highest number of projects investigate power and propulsion and these projects have the highest budget among all subthemes. A similar number of projects, with comparable budgets, focus on the remaining two technical sub-themes, namely hull design and fuels and alternate energy sources. The number of projects falling under the operational and coordination and support measures sub-themes is relatively lower, as well as the related funding.

Table 2. Funding level per sub-theme.

\begin{tabular}{cccc}
\hline Total Funding Action & Number Projects & Total Funding & EU Contribution \\
\hline Hull design & 34 & EUR 199,585,618 & EUR 147,391,833 \\
Power and propulsion & 43 & EUR 238,664,870 & EUR 163,747,778 \\
Fuels and alternative energy sources & 37 & EUR 196,232,303 & EUR 144,362,260 \\
Operational measures & 22 & EUR 96,995,701 & EUR 80,040,301 \\
Coordination and support measures & 23 & EUR 118,709,260 & EUR 81,659,851 \\
\hline Source: Adapted from data available in [35]. & & &
\end{tabular}

The dominance of the power and propulsion sub-theme in waterborne decarbonisation studies is also reflected in the trends in academic publication records, as scientific articles in this domain range from $42 \%$ (2010-2012) to 38\% (2018-2019) of the total articles considered. The second most investigated topics are operational subjects representing $32 \%$ and $37 \%$ over the total articles in 2010-2012 and 2018-2019, respectively. The articles looking at fuels and alternative energy sources issues are around $20 \%$ of the total scientific production, not showing any particular change during the 10 years considered. The articles considering coordination and support measures and hull design aspects are relatively lower, accounting for $6 \%$ and $2 \%$ in 2010-2012 and in 2018-2019, respectively.

All these trends prevail even considering the significantly increased academic publication activities. When looking at the overall scientific production on this specific topic, an increase of $82 \%$ in the total number of scientific publications is evident, from around 3000 articles in 2010-2012 to 5600 in 2018-2019. It should be noted though that in the same time span, there has been an increase of publications in the science areas in Scopus 
considered in this exercise. As a comparison, and with 2010 as a reference, the total number of scientific publications increased by $20 \%$ in 2016 and by $40 \% 2019$. Considering this, still, the normalised increase of the overall scientific production on this specific topic in 2019, compared to 2010, results in little more than $30 \%$.

The quantitative analysis of a number of patents associated with decarbonisation technologies included in the European Patent Office PATSTAT databases also confirms the dominance of the power and propulsion and hull design sub-themes within waterborne decarbonisation research (Figure 4). Nevertheless, the power and propulsion sub-theme increased in share in the last few years. Moreover, patents within the fuels and alternative energy sources sub-theme show an increase over the total share of patents in the last years, while operational and coordination and support measures are less present overall, also confirming the fact that these sub-topics are not directly technology oriented.

A: Percentage of papers by sub-theme

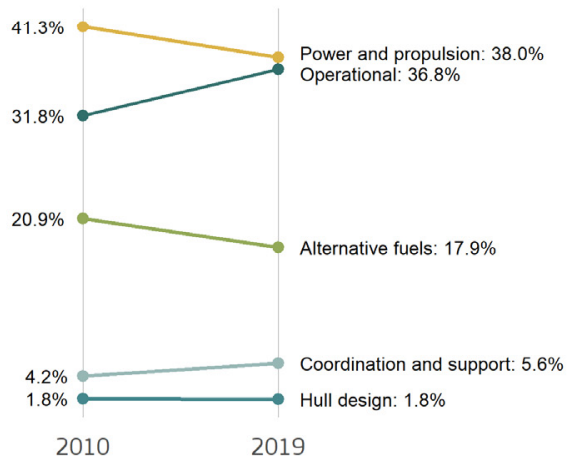

C: Percentage of patents by sub-theme

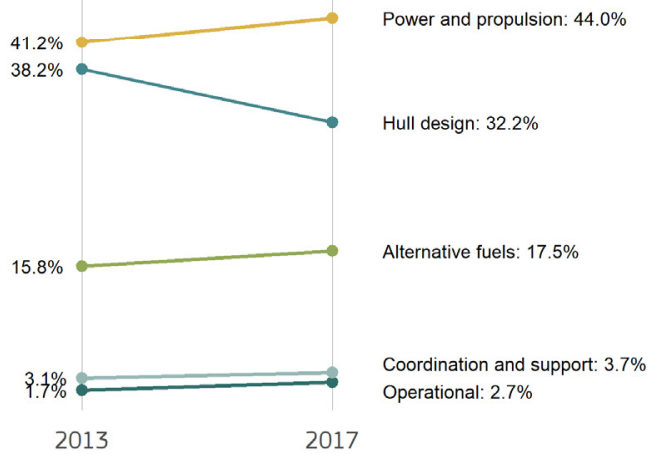

B: Relative increase in number of papers

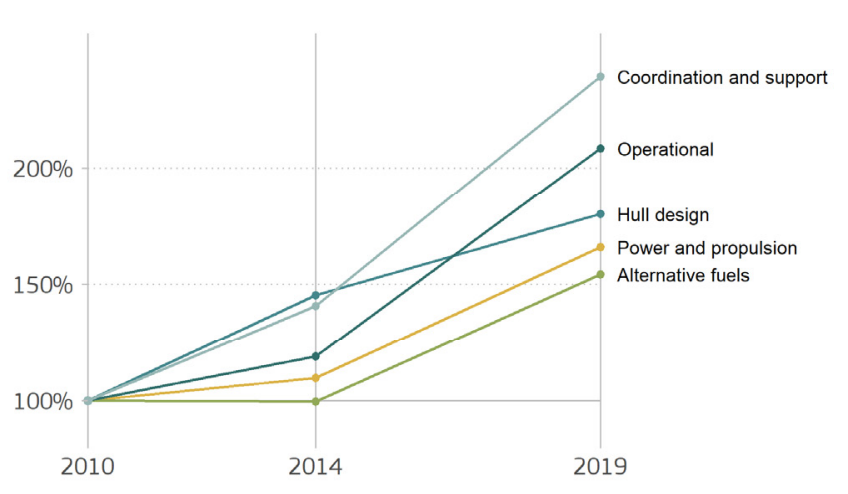

D: Cumulative number of patents

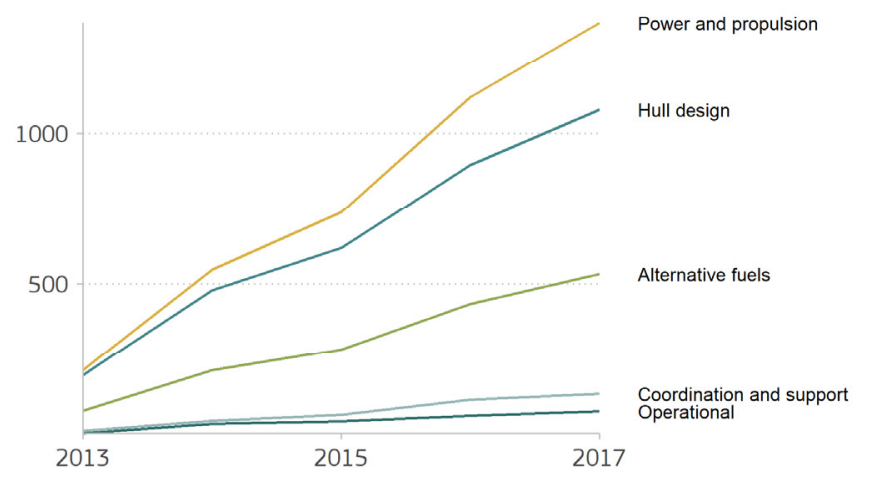

Figure 4. Academic production and patents in waterborne transport decarbonisation. Source: Adapted from data available in [35].

The final part of quantitative assessment summarises the technology maturity breakdown for waterborne projects and the different topics (Figure 5). It is visible that, for all categories, the majority of technologies are under the initial research step, while the number of technologies in the validation, demonstration and implementation stages is quite even, showing that not much difference exists between the various topics. 


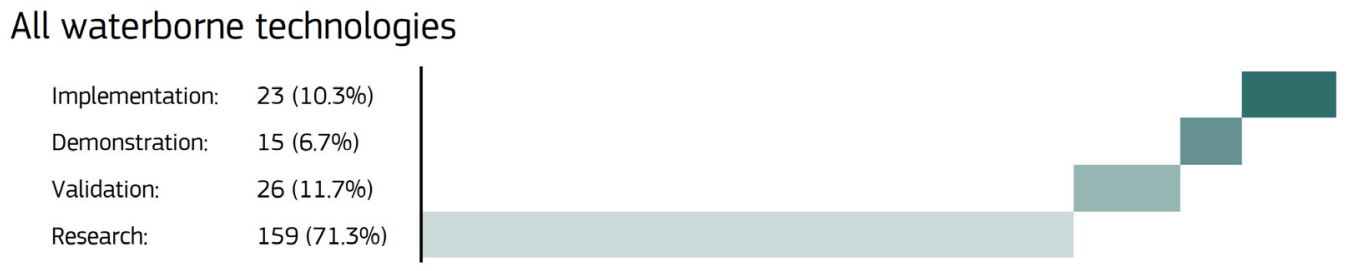

Waterborne decarbonisation technologies

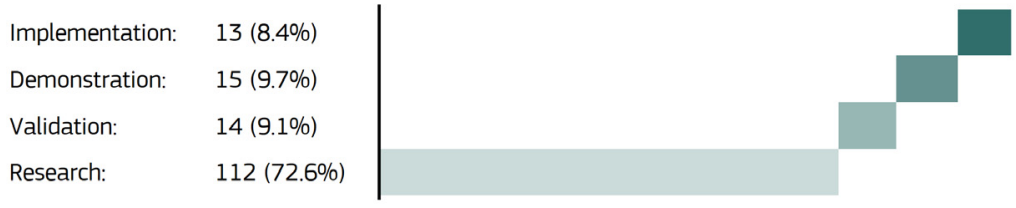

Waterborne decarbonisation technologies: Technical projects

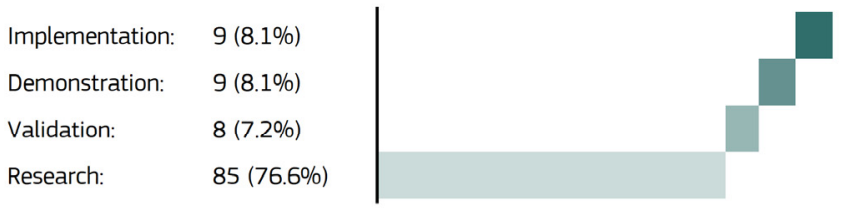

Waterborne decarbonisation technologies: Coordination and support projects

\begin{tabular}{ll|} 
Implementation: & $3(12.5 \%)$ \\
Demonstration: & $5(20.8 \%)$ \\
Validation: & $3(12.5 \%)$ \\
Research: & $13(54.2 \%)$
\end{tabular}

Waterborne decarbonisation technologies: Operational projects

\begin{tabular}{ll|} 
Implementation: & $1(5.3 \%)$ \\
Demonstration. & $1(5.3 \%)$ \\
Validation: & $3(15.8 \%)$ \\
Research: & $14(73.8 \%)$
\end{tabular}

Figure 5. Technology maturity breakdown for waterborne technology and themes division. Reprinted from ref. [35].

\subsection{Qualitative Assessment}

\subsubsection{Sub-Theme 1 -Hull Design}

The research projects within the hull design sub-theme tend to focus on lightweight composite materials for structural components, innovative hull repair methods and hull surface protection. The use of lightweight materials as replacements for heavier materials has the benefit of reducing the overall fuel consumption of the vessel, which subsequently leads to reduced GHG emissions if fossil fuels are used. Another benefit of reducing the vessel energy consumption is that less energy dense fuels (hydrogen, LNG, batteries) may be able to provide sufficient energy to power the vessel, hence paving the way for alternative fuels use in the maritime sector.

The review of the projects of this sub-theme shows that there is interest in using composite materials for conventionally fuelled ships; friction stir welding technology should allow ships built from conventional steel to be made lighter, with consequent improvements in efficiency. Some of the benefits linked to such technologies have been listed in Table 3 (This and the following tables illustrating European projects results and benefits cannot be considered comprehensive of the overall projects outcome as a selection of information was done for the purpose of this paper and information may not be easily accessible for 
all projects) which identifies efficiency improvement associated to fuel savings, weight reduction and possible cost savings. Prototypes were also built into the model or at a large scale, and were assessed in terms of technical properties, safety issues and economic and ecological impacts (e.g., ADAM4EVE, MOSAIC projects).

Table 3. Hull design projects: expected benefits.

\begin{tabular}{|c|c|c|c|}
\hline Project Acronym & Key Themes & Expected/Proved Benefits & Main Benefits Estimation \\
\hline ADAM4EVE & $\begin{array}{l}\text { Adaptive hull structures; } \\
\text { smart materials }\end{array}$ & $\begin{array}{l}\text { Fuel savings due to: retractable stern } \\
\text { flap, lightweight panels, adaptive } \\
\text { bulbous bow. }\end{array}$ & $\begin{array}{l}\text { Yearly fuel saving of } \sim 5.6 \% \text { of retractable } \\
\text { stern flap }\end{array}$ \\
\hline HILDA & Friction stir welding & $\begin{array}{l}\text { System and software for using friction } \\
\text { stir welding in industrial settings }\end{array}$ & $\begin{array}{l}\text { Potential cost saving per welder per year: } \\
-€ 390 \text { no molten metal injuries; } \\
-€ 160 \text { no UV exposure; } \\
\text {-€750 reduced training and certification }\end{array}$ \\
\hline LEAF & $\begin{array}{l}\text { Hull surface antifouling } \\
\text { technology }\end{array}$ & $\begin{array}{l}\text { New antifouling technology without } \\
\text { biocide emission and low adhesion }\end{array}$ & $\begin{array}{l}\text { Antifouling efficiency for a wide range of } \\
\text { organisms; low biocide release rates; lower } \\
\text { environmental impact (global warming, } \\
\text { acidification, eutrophication potentials; } \\
\text { lower production costs. }\end{array}$ \\
\hline MOSAIC & High-strength low-alloy steels & $\begin{array}{l}\text { High Strength Low Alloyed Steels and } \\
\text { replacement of ship's structural parts } \\
\text { with composite materials. }\end{array}$ & $\begin{array}{c}\text { Weight savings of } \sim 30 \% \text {; reduced material } \\
\text { wastage and repair costs due to no corrosion } \\
\text { of composite materials }\end{array}$ \\
\hline FIBRESHIP & Fibre reinforce polymers & $\begin{array}{l}\text { Design and construction of vessels } \\
\text { greater than } 500 \mathrm{GT} \\
\text { in lightweight fibre reinforce polymers }\end{array}$ & $\begin{array}{l}\text { Up to } 36 \% \text { overall weight reduction; } \\
\text { bunkering consumption reduction; lower } \\
\text { GHG Emissions; increasing } \\
\text { payload/passenger capacity }\end{array}$ \\
\hline COMPA 2GO & Smart repair service & $\begin{array}{c}\text { Composite patch repair for damaged } \\
\text { ship pipes }\end{array}$ & DNV GL certification \\
\hline
\end{tabular}

Source: Adapted from data available in [35].

Still, some future research should focus on joint implementation of composite materials with alternatively-fuelled vessels and on the wider-scale uptake applied to the whole fleet (e.g., as result of the LEAF project). Tooling issues remain a challenge in using this technology which appeared as a result of the HILDA project; in case of implementation on a large scale, this aspect would need to be investigated and mitigated accordingly. Future research could look for solutions to these problems, enabling the technology to be employed on a large scale. The research on the use of composite materials in ship manufacture is progressing towards implementation. However, due to fire hazards at present, IMO 'Safety of life at sea' rules limit the use of such materials to vessels of less than 500 tonnes gross weight. There may be a need to work at an international level to review and potentially revise the regulations to allow the use of advance materials in larger vessels, considering also the energy return of investment (EROI) linked to such technologies. Technologies to reduce ship resistance due to fouling of the hull by barnacles without harming the environment with toxic substances, were demonstrated to improve ship performance, leading to potential fuel savings ranging from $0.1 \%$ to $30 \%$, according to different types of technologies $[10,11]$. Future research steps in this area should focus on an environmentally friendly coating with extended durability applicable to the full fleet. These technologies allow efficiency improvements, which nonetheless cannot be considered as a standalone solution to meet the challenging ambition of the EU Green Deal. Therefore, additional research should focus on combined solutions, which are capable of delivering significant greater reductions as well as addressing the recyclability of such materials.

\subsubsection{Sub-Theme 2-Power and Propulsion}

Projects under the power and propulsion sub-theme focus on topic areas such as wind assisted propulsion, increases in engine efficiency and recycling of waste heat for use elsewhere in the vessel. All of the technologies in this sub-theme relate to reducing the 
overall energy consumption of the vessel either directly or indirectly. Improving engine efficiency will increase the energy obtained from the fuel used, and therefore will reduce the total volume of fuel required to perform the same operations. Auxiliary systems, e.g., heating and cooling of the cabin, are traditionally powered using the same fossil-fuel source as the engine, which increases the overall vessel's energy consumption. By using the waste heat from the engine to power the auxiliary system, fuel is saved and therefore GHG emissions are reduced. The range of $\mathrm{CO}_{2}$ reduction estimation is wide, ranging from $1 \%$ to $25 \%$ and associated to the different technologies in place, as extensively summarised in [10] and [11]. Moreover, multiple European research projects have demonstrated reductions in fuel consumption using different propulsion concepts. A selection of those is shown in Table 4, which includes some of the estimated benefits identified from their implementation.

Table 4. Power and propulsion projects: expected benefits.

\begin{tabular}{|c|c|c|c|}
\hline Project Acronym & Key Themes & Expected/Proved Benefits & Main Benefits Estimation \\
\hline RotorDEMO & Wind assisted propulsion & $\begin{array}{c}\text { Implementation, validation, update of } \\
\text { commercialisation plan of Norsepower } \\
\text { Rotor Sail Solution in full scale on a } \\
\text { RoPax vessel. }\end{array}$ & $\begin{array}{c}\text { Fuel savings of between } 231 \text { to } 315 \text { tonnes } \\
\text { per year, resulting in } \sim 900 \text { tonnes less of } \mathrm{CO}_{2} \\
\text { per year (for RoPax) }\end{array}$ \\
\hline GFF & Fully electric ferry & $\begin{array}{l}\text { Implementation, validation, update of } \\
\text { commercialisation plan of the GFF for } \\
\text { potential customers }\end{array}$ & $\begin{array}{l}\text { Zero emissions ferry able to sail at a } 55 \\
\mathrm{~km} / \mathrm{h} \text { speed, with autonomy of } 26 \mathrm{~km} \text { routes } \\
\text { in } 30 \text { min and fast recharge at port }<20 \mathrm{~min} \text {. } \\
\text { Reduced energy consumption by up to } 40 \% \text {. }\end{array}$ \\
\hline EEECSM-2 & Waste heat to energy & $\begin{array}{c}\text { Reuse waste heat to power heating and } \\
\text { cooling systems, optimise on board } \\
\text { energy circulation }\end{array}$ & $\begin{array}{c}\text { Fuel savings of } \sim 340 \text { tonnes per year, } \\
\text { resulting in } \sim 1200 \text { tonnes less of } \mathrm{CO}_{2} \text { per } \\
\text { year. Cooling operating expenses reduced by } \\
\text { up to } 94 \% \text {. }\end{array}$ \\
\hline LeanShips & $\begin{array}{l}\text { Increased engine efficiency, } \\
\text { emissions abatement } \\
\text { technologies }\end{array}$ & $\begin{array}{l}\text { Multiple technology demonstrators (e.g., } \\
\text { conversion of a diesel engine to a } \\
\text { dual-fuel engine with methanol) }\end{array}$ & $\begin{array}{c}\text { Energy savings of } 12 \%, \mathrm{CO}_{2} \text { savings of } 14 \% \text {, } \\
\text { Reduction of } 60 \% \text { NOx, } 70 \% \text { SOx and } 77 \% \\
\text { PM. }\end{array}$ \\
\hline HERCULES-2 & $\begin{array}{l}\text { Increased engine efficiency, } \\
\text { fuel-flexible engines }\end{array}$ & $\begin{array}{l}\text { Fuel flexibility, new materials for high } \\
\text { temperature component applications, } \\
\text { adaptive control methodologies, } \\
\text { achieving near-zero emissions, } \\
\text { combining an integrated approach after } \\
\text { treatment of exhaust gases. }\end{array}$ & $\begin{array}{l}\text { Up to a } 25 \% \text { reduction in GHG emissions } \\
\text { using a fuel flexible engine. A } 50 \% \text { longer } \\
\text { engine lifetime using new materials. } \\
\text { Total of } 80 \% \text { NOx emissions reduction with } \\
\text { the integration of an After Treatment Unit } \\
\text { (ATU) into existing engine structure in } \\
\text { very large engines. }\end{array}$ \\
\hline
\end{tabular}

Source: Adapted from data available in [35]

As separate technologies provide fuel consumption improvements, future research should investigate how the combination of different technologies onto a single ship could enhanced such positive effects within real world conditions. Wind propulsion has been shown to produce savings in fuel consumption, particularly at lower speeds and certain routes. To demonstrate its benefits and to increase market penetration, reliability and performance must be proven at a large scale and within harsh marine environments. Reductions in fuel consumption can be obtained by using waste heat from engines that can then be used to power a ship's heating and cooling systems, which could lead to a $0-4 \%$ fuel savings [10], hence future policy could encourage operators to adopt this technology. Applications in the domain of vessel electrification have shown successful results, namely in cases of fully electric high-speed passenger ferries. Future policy could assist in increasing the range and scale of battery electric applications and to expand to other types of vessels (i.e., inland waterway and urban commuter vessels) which may potentially be commercialised more quickly.

\subsubsection{Sub-Theme 3-Fuels and Alternative Energy Sources}

Current research projects under the fuels and alternative energy sources category relate to the use of electrification (batteries, hybrid systems), hydrogen as a fuel and natural gas/LPG as a fuel. The benefits of alternative fuels in terms of decarbonisation are clear; by 
reducing the carbon content of the fuel or eliminating the tailpipe emissions, it is possible to reduce the overall GHG emissions of the vessels. Hydrogen and battery vessel emissions will depend directly on the upstream, carbon content of producing the fuel/energy, emissions in generating the electricity or producing the hydrogen. As such, there are research projects investigating the use of battery vessels, which use $100 \%$ renewable electricity. Still uncertainty remains on the implementation of these technologies at a big scale and where the EROI of the overall process needs to be considered too [43].

The assessment of projects under the sub-theme on fuels and alternative energy sources, as illustrated in Table 5, shows that a number of alternative fuels are under consideration for decarbonising the waterborne sector, which can help with achieving the desired European emissions targets.

Table 5. Fuels and alternative energy sources projects: expected benefits.

\begin{tabular}{|c|c|c|c|}
\hline Project Acronym & Key Themes & Expected/Proved Benefits & Main Benefits Estimation \\
\hline BB Green & $\begin{array}{l}\text { Vessel electrification; } \\
\text { reduced hull resistance }\end{array}$ & $\begin{array}{l}\text { New vessel to run entirely on renewable } \\
\text { energy, with an on-board battery }\end{array}$ & $40 \%$ reduction of hull water resistance \\
\hline PURE & $\begin{array}{l}\text { Fuel-cell auxiliary power } \\
\text { unit }\end{array}$ & $\begin{array}{l}\text { Delivery of electrical power sufficient to } \\
\text { cover power demand from } \\
\text { heating/cooling, etc., of a small yacht }\end{array}$ & $\begin{array}{l}\sim 25 \% \text { system efficiency, low noise and no } \\
\text { smells }\end{array}$ \\
\hline E-ferry & Fully-electric ferry & $\begin{array}{l}\text { Design concept and demonstrate a } 100 \% \\
\text { electric, emission free, medium sized ferry } \\
\text { for passengers and cargo in full-scale } \\
\text { operation on longer distances than } \\
\text { previously seen ( }>5 \text { nautical miles) }\end{array}$ & $\begin{array}{c}\text { Annual vessel reduction of } \mathrm{CO}_{2} \text { emissions } \\
\text { by } 2000 \text { tonnes, } 41,500 \mathrm{~kg} \mathrm{NOx}, 1350 \mathrm{~kg} \\
\mathrm{SO}_{2} \text { and } 2500 \mathrm{~kg} \mathrm{PM}\end{array}$ \\
\hline MARANDA & $\begin{array}{l}\text { Hybrid fuel-cell powertrain } \\
\text { system }\end{array}$ & $\begin{array}{l}\text { Hydrogen fuelled proton exchange } \\
\text { membrane fuel cell hybrid powertrain } \\
\text { system for maritime applications with a } \\
\text { powertrain power of around } 165 \mathrm{~kW} \text {. }\end{array}$ & $\begin{array}{c}\sim 50 \% \text { system efficiency, freeze start } \\
\text { capabilities from }-35^{\circ} \mathrm{C} \text {, operating } \\
\text { temperature from }-32^{\circ} \text { to }+50^{\circ} \text {, fuel cell } \\
\text { stack life of } 15,000 \mathrm{~h}\end{array}$ \\
\hline HyMethShip & $\begin{array}{l}\text { Hydrogen-methanol } \\
\text { propulsion system }\end{array}$ & $\begin{array}{l}\text { Develop a hydrogen-methanol ship } \\
\text { propulsion system using on-board } \\
\text { pre-combustion carbon capture. }\end{array}$ & $\begin{array}{l}\text { Target: GHG emissions by more than } 97 \% \text {, } \\
\text { compared to conventional fuels, } \\
\text { eliminating SOx and PM emissions. } \\
\text { Increased energy efficiency of } 45 \% \\
\text { compared to best available technology }\end{array}$ \\
\hline
\end{tabular}

Source: Adapted from data available in [35].

However, the ideal mix is not currently clear, as some potential sustainability, infrastructure and distribution drawbacks are associated with these options, as in the case of biofuels, bio-methane, ammonia, hydrogen or methanol $[10,11]$. There would be benefits in investigating the advantages and disadvantages of the various alternative fuels under different waterborne applications, taking into account their energy return of investments, which may support scaling up of production as well as their use in vessel engines.

For the short-term, alternative lower-carbon fossil fuels, such as LNG, LPG and CNG are being suggested as a means to achieve a rapid reduction in pollutions from shipping. However, their contribution to decarbonisation is limited, as it depends on the engine type and release of unburnt methane. Further consideration is required on how the transition from such fuels should be managed in order to pave the way towards low fossil carbon fuels. It should be investigated whether transitional fuels such as bio LNG, bio-diesel, ammonia, methanol or hydrogen may be a distraction from the development of longer-term low, or zero, carbon fuels, risking infrastructure investment which may become stranded assets.

Multiple projects have explored the use of battery technology for vessels using different battery chemistries. Although this technology seems to be very efficient, the most promising applications are the ones on short distances, due the large amount of energy required. Future research could be conducted into the benefits and disadvantages of different battery chemistries, including the weight ratio, for different ship applications (i.e., ship weight and cargo) to assist vessel designers in choosing the optimum option for a new vessel. The greatest impacts on decarbonisation of the waterborne transport sector 
are likely to come from the use of alternative energy sources. For example, electricity from renewable sources or hydrogen from electrolysis can offer a pathway to net zero for the waterborne transport industry.

\subsubsection{Sub-Theme 4-Operational Measures}

Projects under the operational measures sub theme address topics such as improved vessel navigation, vessel allocation systems and robotic container handling systems. These operational measures can have potential to increase efficiency and therefore reduce overall fuel consumption by up to $83 \%$ based on the measure implemented [10,11]. This can have a benefit in reducing GHG emissions from maritime operations.

In this domain, the main findings indicate that the development of robotic container management systems has progressed to the production of design approaches for different sub-systems. Moreover, fully robotic container terminals are already operational worldwide. A selection of such measures is shown in Table 6, illustrating the benefits derived from some European projects.

Table 6. Operational measures projects: expected benefits.

\begin{tabular}{|c|c|c|c|}
\hline Project Acronym & Key Themes & Expected/Proved Benefits & Main Benefits Estimation \\
\hline RCMS & $\begin{array}{l}\text { Robotic container } \\
\text { management system }\end{array}$ & $\begin{array}{l}\text { Efficient terminal design, } \\
\text { validated and quantified benefits also } \\
\text { related to noise and air pollution }\end{array}$ & $\begin{array}{l}\text { Costs can be reduced by around } 20 \% \text {. } \\
\text { RCMS can be the only solution for } \\
\text { specific ports. }\end{array}$ \\
\hline CLOUD-VAS & $\begin{array}{l}\text { Cloud-based vessel } \\
\text { allocation }\end{array}$ & $\begin{array}{l}\text { Flexible and affordable optimisation } \\
\text { platform to minimise operational costs } \\
\text { and fuel consumption }\end{array}$ & $\begin{array}{l}\text { Up to } 75 \% \text { timesaving compared to } \\
\text { traditional vessel allocation tools }\end{array}$ \\
\hline LOGIMATIC & $\begin{array}{l}\text { Global Navigation } \\
\text { Satellite Systems } \\
\text { (GNSS); route } \\
\text { planning }\end{array}$ & $\begin{array}{l}\text { Continuous, reliable and accurate } \\
\text { estimation of the position and velocity } \\
\text { of platforms, enabling resource and } \\
\text { space optimisation. }\end{array}$ & $\begin{array}{l}\text { Use of electric mechanical traction, } \\
\text { reducing fuel consumption and } \mathrm{CO}_{2} \text { by } \\
\sim 50 \%\end{array}$ \\
\hline SHIPLYS & $\begin{array}{l}\text { Virtual prototyping, } \\
\text { life-cycle assessment }\end{array}$ & $\begin{array}{l}\text { Increase production efficiency, reduce } \\
\text { energy consumption, environmental } \\
\text { impacts and production costs both in } \\
\text { shipyards and vessels in operation }\end{array}$ & Benefits reported for different scenarios \\
\hline $\mathrm{H} 2 \mathrm{H}$ & Safe vessel navigation & $\begin{array}{l}\text { Increase navigation safety when in the } \\
\text { proximity of other vessels or objects. }\end{array}$ & Benefits not directly quantified \\
\hline AUTOSHIP & Autonomous vessels & $\begin{array}{c}\text { Demonstration of autonomous vessels } \\
\text { in real short sea shipping and inland } \\
\text { waterway environments. }\end{array}$ & Benefits not directly quantified \\
\hline
\end{tabular}

Source: Adapted from data available in [35].

Thus, research should focus on the integration of on shore automated systems with smart scheduling and potentially automated ships, as well as integration of logistic chains and operational measures to reduce GHG emissions (e.g., slower sailing speeds). Interoperability of technologies at different ports around the world is important. Although benefits have been identified for vessel management systems at ports, it is important that the implemented solutions can be used by all ships, particularly by those which apply operation GHG reduction measures. Policy could be developed for all European ports wishing to use these technologies, to create a standard approach to navigation and smart vessel scheduling as well as the seamless integration between port arrivals and GHG efficient hinterland connections. Projects have demonstrated the benefits of Global Navigation Satellite Systems (GNSS) for automated maritime shipping and integrated logistics. This technology could further improve vessels efficiencies, and could reduce fuel consumption and emissions. Further research should investigate how the GNSS technologies would interact with autonomous ship technologies, as well as how to increase safety and ensure the resilience of GNSS based systems against failure or malicious intervention. In the 
domain of autonomous ships, research has been recommended on regulations, rules and standards for autonomous ships. In this field, research should include the definition and level of responsibility for the different crew members, the role of human operators on board and the allowed/needed manual operations. Moreover, the management of compulsory systems, devices and procedures that would facilitate crewless vessel operation should be investigated further, as well as the role and responsibilities of remote-control centres. Policy aligned across all Member States could be developed to include safe operation of autonomous vessels, including safe operation within complex mixed traffic, integration within logistic chains and resilience against the consequences of system failure.

\subsubsection{Sub-Theme 5-Coordination and Support Measures}

Projects under the coordination and support measures sub-theme focus on the research coordination and dissemination within the waterborne transport sector, rather than technological measures, therefore the quantification of possible emission reduction is rather difficult to capture. They include planning and future strategies for the sector, looking both at vessel and port design. As new technologies become more developed, it becomes increasingly important that the results and benefits of these new technologies are relayed to the stakeholders in the waterborne transport sector. This will help to increase the uptake of new and innovative technologies which are focused on decarbonisation.

Results of the industry/market trends to 2030 should be reviewed to consider the socio-economic impacts, such as the Coronavirus disease 2019 (COVID-19) pandemic, and assess whether the impacts on the maritime market are likely to be long lasting.

Further policy development may be needed to ensure that the 2030 decarbonisation targets are met, and that the industry is aware of what needs to be done to reach these targets. Previous projects have investigated trends and expectations of the maritime industry up to the year 2030. Future research should extend this time period towards 2050 to fit in line with the Green Deal targets. It is important to capture the long-term expected market trends such that the long-term decarbonisation targets can be met and adjusted accordingly. Research into the application of telematics solutions to maritime shipping has shown relatively low potential uptake in the markets investigated. Further research in this domain could help with understanding the reasons and how to increase uptake.

\section{Discussion and Conclusions}

This paper focuses on selected EU funded projects and presents a comprehensive analysis of R\&I in the field of waterborne transport decarbonisation in Europe. It identifies relevant technologies related to hull design, power and propulsion and fuels and alternative energy sources, as well as operational, coordination and support measures aimed at decreasing the impact of waterborne transport $\mathrm{CO}_{2}$ emissions. The analysis is complemented by the findings on the evolution of international scientific publications and patents associated to waterborne transport decarbonisation technologies.

Nearly one billion Euro has been invested in waterborne transport decarbonisation research projects realised under FP7 and H2020. Three quarters of this amount came from EU funds while the rest (EUR 239 million) from contributions by beneficiary organisations. The importance of the decarbonisation theme in waterborne transport, underlined both at the European and international level, is also reflected by share of waterborne R\&I projects dedicated to this issue. Approximately $65 \%$ of waterborne transport projects in FP7 and H2020 deal with decarbonisation. The majority are technical projects followed by operational and coordination and support measures projects.

All waterborne decarbonisation FP7 and H2020 projects were grouped within one or more of five identified sub-themes. The technical subthemes (i.e., hull design, power and propulsion and fuels and alternate energy sources) dominate EU funded waterborne research. Combined, they were studied in $85 \%$ of projects.

Further, within the three technical oriented subthemes, the fuels and alternate energy sources is the one with the highest increased budget, when comparing FP7 and H2020 
projects. Hull design has a similar share in both framework programmes, while projects related to the power and propulsion subtheme have lower budgets. Power and propulsion topics are the most intensively investigated in global academic research. The same pattern emerges from the analysis of waterborne-related patents granted by PATSTAT during the years 2013-2017.

As stated, the EU actions aiming at reducing waterborne transport emissions include a wide range of technological solutions, operational measures and support and coordination actions. Depending on vessel and cargo specification, as well as geographical and route characteristics, the applicability of different measures may differ. However, even though there seems to not be a single measure which can be considered as a problem solver, the combination of the following innovations should provide significant improvement in energy efficiency and environmental benefits. The most promising recent European projects dealing with hull design technologies focus on the implementation of lightweight composite materials. Additionally, they cover innovative repair methods and hull surface protection methods, which provide additional cost savings. The innovation in power and propulsion technologies focuses on increased energy efficiency, thereby providing important environmental benefits. The use of wind propulsion and reuse waste heat bring up to $14 \%$ of overall $\mathrm{CO}_{2}$ reduction (e.g., LeanShips project) or up to $40 \%$ reduction of energy consumption (e.g., GFF project). Fuels and alternate energy sources represent one of the most promising technological areas in relation to maritime decarbonisation. The previous studies as well as applications developed within European projects have showed that electricity from renewable sources or hydrogen from electrolysis can offer a pathway to net zero for the waterborne transport industry. Moreover, operational measures can substantially help in decreasing maritime emissions, mainly through adjusted vessel navigation speed and allocation and the support of port handling systems. As literature has shown, speed reduction can reduce up to $80 \%$ of $\mathrm{CO}_{2}$ [11] and vessel allocation together with an innovative port system can decrease operational time and costs (e.g., CLOUDVAS and LOGIMATIC projects). Finally, coordination and support measures prepare and support ground for collaborative R\&I environments, leading to increased efficiency and reduced negative environmental impacts of maritime transport.

The analysis conducted in this paper focuses on the achievement of FP7 and H2020 projects on the waterborne decarbonisation theme and the related R\&I and policy recommendations naturally emerged from their main findings, hence no indications can be provided on additional or not yet explored research on the topic. It should nonetheless be highlighted that increasing interest is given to this research area, as clearly presented in the draft proposal for the European partnership on Zero-Emission Waterborne Transport under the upcoming Horizon Europe programme [44]. In the proposal, particular emphasis is posed on research themes such as: increasing use of sustainable alternative fuels, electrification, increasing energy-efficiency, design and retrofitting solutions for the new and existing fleet, digital green to improve efficiency and sustainable bunkering and charging solutions for climate neutral ships.

This paper, by providing a comprehensive and up-to-date review of waterborne transport decarbonisation R\&I across Europe, may help transport researchers, policy makers, regulators and transport companies in shaping future research, policy measures and business strategies in this domain. This paper is based on a TRIMIS report on R\&I in waterborne transport decarbonisation in Europe, which is the first of a series of reports addressing specific transport modes, followed by similar ones on aviation and rail transport. Through the continuous effort in consolidating and expanding the TRIMIS data repository, the TRIMIS analyses aim to better capture R\&I efforts beyond the currently included funding means and to provide more accurate details on the technology assessment which will be further refined.

Nevertheless, the analyses presented in the paper face some limitations which should be addressed in future research. First, TRIMIS focuses on publicly funded projects, therefore private initiatives are not fully considered. Moreover, Member States funding information 
is fragmented and hence has not been fully included in this paper. Thus, even though the presented results cover the main trends in waterborne R\&I at the European level, further analysis is necessary of research financed by private entities or Member State funds. Second, the study identify decarbonisation as the most important and challenging issue in waterborne research and thus focuses on this topic. As a consequence, waterborne transport projects loosely linked to the decarbonisation topic have not been included. Finally, the technology assessment should be further refined and updated as new research results enter the market. The methodology behind the text analysis on waterborne transport decarbonisation in academic research should also be further developed.

Author Contributions: Conceptualization, M.G., F.L.M.d.S., K.G. and M.S.; methodology, M.G., F.L.M.d.S., K.G. and M.S.; software, F.L.M.d.S., K.G. and M.S.; validation, M.G. and F.P.; formal analysis, M.G., F.L.M.d.S., K.G. and M.S.; investigation, M.G., F.L.M.d.S. and K.G.; resources, F.P.; data curation, M.G., F.L.M.d.S., K.G. and M.S.; writing-original draft preparation, M.G.; writingreview and editing, M.G., F.L.M.d.S., K.G., M.S. and F.P.; visualization, F.L.M.d.S., M.S.; supervision, F.P.; project administration, F.P.; funding acquisition, F.P. All authors have read and agreed to the published version of the manuscript.

Funding: This research received funding from the Horizon 2020 Framework Programme for Research and Innovation.

Institutional Review Board Statement: Not applicable.

Informed Consent Statement: Not applicable.

Data Availability Statement: Publicly available datasets were analysed in this study. The TRIMIS Database can be found at: TRIMIS. Available online: https:/ / trimis.ec.europa.eu (accessed on 24 August 2021).

Acknowledgments: The European Commission's Joint Research Centre (JRC) is responsible for the development of the Transport Research and Innovation Monitoring and Information System (TRIMIS). The work has been carried out under the supervision of the European Commission's Directorate-General for Mobility and Transport (DG MOVE) and Directorate-General for Research and Innovation (DG RTD) which are co-leading the Strategic Transport Research and Innovation Agenda (STRIA). The presented paper is based on the report "Waterborne transport in Europe-the role of Research and Innovation in decarbonisation" published by Publications Office of the European Union (2021). The authors would like to acknowledge the support of Ricardo-AEA Ltd. and the useful comments received during the 2021 WCTRS-SIGA2 Conference from various participants. The views expressed here are those of the authors and may not, under any circumstances, be regarded as an official position of the European Commission.

Conflicts of Interest: The authors declare no conflict of interest.

\section{Glossary}

$\begin{array}{ll}\text { ATU } & \text { After Treatment Unit } \\ \text { CNG } & \text { Compressed natural gas } \\ \text { CORSIA } & \text { Carbon Offsetting and Reduction Scheme for International Aviation } \\ \text { COVID-19 } & \text { Coronavirus disease 2019 } \\ \text { CPC } & \text { Cooperative patent classification } \\ \text { DG MOVE } & \text { Directorate-General for Mobility and Transport } \\ \text { DG RTD } & \text { Directorate-General for Research and Innovation } \\ \text { EC } & \text { European Commission } \\ \text { EEDI } & \text { Energy Efficiency Design Index } \\ \text { EPO } & \text { European patent office } \\ \text { EROI } & \text { Energy Return of Investment } \\ \text { EU } & \text { European Union } \\ \text { EU-27 } & \text { 27 EU Member States } \\ \text { EU ETS } & \text { EU Emissions Trading System } \\ \text { FP } & \text { European Framework Programme for research and innovation }\end{array}$




$\begin{array}{ll}\text { FP7 } & \text { 7th Framework Program for Research } \\ \text { GHG } & \text { Greenhouse gas } \\ \text { GNSS } & \text { Global Navigation Satellite Systems } \\ \text { H2020 } & \text { Horizon 2020 Framework Program for Research and Innovation } \\ \text { HFO } & \text { Heavy fuel oil } \\ \text { ICAO } & \text { International Civil Aviation Organisation } \\ \text { IMO } & \text { International Maritime Organisation } \\ \text { JRC } & \text { Joint Research Centre } \\ \text { LNG } & \text { Liquefied natural gas } \\ \text { LPG } & \text { Liquefied petroleum gas } \\ \text { MARPOL } & \text { International Convention for the Prevention of Pollution from Ships } \\ \text { MRV } & \text { Monitoring, reporting and verification } \\ \text { NASA } & \text { National Aeronautics and Space Administration } \\ \text { PATSTAT } & \text { EPO Worldwide Patent Statistical Database } \\ \text { R\&I } & \text { Research and Innovation } \\ \text { REGEX } & \text { Regular expression } \\ \text { SEEMP } & \text { Ship energy efficiency management plan } \\ \text { STRIA } & \text { Strategic Transport Research and Innovation Agenda } \\ \text { TRIMIS } & \text { Transport Research and Innovation Monitoring and Information System } \\ \text { TRL } & \text { Technology readiness level } \\ \text { WASP } & \text { Wind-assisted ship propulsion }\end{array}$

\section{Appendix A. Regular Expressions (REGEX) Used for Scopus Database Keywords Analysis}

Table A1. Waterborne Transport Sub-Themes (left) and corresponding REGEX (right).

\begin{tabular}{|c|c|}
\hline Waterborne Transport Sub-Theme & Regular Expressions \\
\hline Hull design & $\begin{array}{c}\text { ((DOCTYPE(ar) or DOCTYPE }(\mathrm{cp})) \text { and TITLE-ABS (("hull design" or "hull } \\
\text { structure" or "Hull weight" or "Bulbous bow" or "Hull shape") and (boat or ship } \\
\text { or ferry or vessel) and not "electric field") AND PUBYEAR > } 2009 \text { AND } \\
\text { PUBYEAR < } 2020 \text { and not SUBJAREA(MEDI OR NURS OR VETE OR DENT OR } \\
\text { HEAL OR MULT)) }\end{array}$ \\
\hline Power and propulsion & $\begin{array}{c}\text { ((DOCTYPE(ar) or DOCTYPE(cp)) and TITLE-ABS(engine or power or propulsion } \\
\text { and (boat or ship or ferry or vessel)) AND PUBYEAR > } 2009 \text { AND } \\
\text { PUBYEAR }<2020 \text { and not SUBJAREA(MEDI OR NURS OR VETE OR DENT OR } \\
\text { HEAL OR MULT)) }\end{array}$ \\
\hline Fuels and alternative energy sources & $\begin{array}{c}\text { ((DOCTYPE(ar) or DOCTYPE }(\mathrm{cp})) \text { and TITLE-ABS ((electric or lpg or batter* or } \\
\text { hybrid or hydrogen or methanol) and (boat or ship or ferry or vessel) and not } \\
\text { "electric field" and not "pressure vessel" and not "spherical vessel") AND } \\
\text { PUBYEAR > } 2009 \text { AND PUBYEAR < } 2020 \text { and not SUBJAREA(MEDI OR NURS } \\
\text { OR VETE OR DENT OR HEAL OR MULT)) }\end{array}$ \\
\hline Operational measures & $\begin{array}{c}\text { ((DOCTYPE(ar) or DOCTYPE }(\mathrm{cp})) \text { and TITLE-ABS ((electric or lpg or batter* or } \\
\text { hybrid or hydrogen or methanol) and (boat or ship or ferry or vessel) and not } \\
\text { "electric field" and not "pressure vessel" and not "spherical vessel") AND } \\
\text { PUBYEAR > } 2009 \text { AND PUBYEAR < } 2020 \text { and not SUBJAREA(MEDI OR NURS } \\
\text { OR VETE OR DENT OR HEAL OR MULT)) }\end{array}$ \\
\hline Coordination and support measures & $\begin{array}{l}\text { ((DOCTYPE(ar) or DOCTYPE(cp)) and TITLE-ABS(standardization or “Market } \\
\text { instrument" or Regulation or “Trading market" or "Emission Trading" and (boat } \\
\text { or ship or ferry)) AND PUBYEAR > 2009 AND PUBYEAR < } 2020 \text { and not } \\
\text { SUBJAREA(MEDI OR NURS OR VETE OR DENT OR HEAL OR MULT)) }\end{array}$ \\
\hline
\end{tabular}

\section{References}

1. UNCTAD. Review of Maritime Transport 2019; United Nations Publications: New York, NY, USA, 2019.

2. European Commission. Directorate-General for Mobility and Transport; Statistical Pocketbook 2019-Transport in Figures; European Commission: Brussels, Belgium, 2019. Available online: https:/ / ec.europa.eu/transport/facts-fundings/statistics/pocketbook2019_en (accessed on 17 September 2021). 
3. European Commission. The EU Blue Economy Report; Publications Office of the European Union: Luxembourg, 2020.

4. IMO. Fourth IMO GHG Study 2020; International Maritime Organization (IMO): London, UK, 2020.

5. Psaraftis, H.N.; Kontovas, C.A. Decarbonization of Maritime Transport: Is There Light at the End of the Tunnel? Sustainability 2021, 13, 237. [CrossRef]

6. Serra, P.; Fancello, G. Towards the IMO's GHG goals: A critical overview of the perspectives and challenges of the main op-tions for decarbonizing international shipping. Sustainability 2020, 12, 3220. [CrossRef]

7. European Commission. The European Green Deal, Communication from the Commission to the European Parliament, the European Council, the Council, the European Economic and Social Committee and the Committee of the Regions; COM(2019)640 Final; European Commission: Brussels, Belgium, 2019.

8. European Commission. Sustainable and Smart Mobility Strategy-Putting European transport on track for the future, Communication from the Commission to the European Parliament, the Council, the European Economic and Social Committee and the Committee of the Regions; COM/2020/789 Final; European Commission: Brussels, Belgium, 2020.

9. European Commission. Integrating Maritime Transport Emissions in the EU's Greenhouse gas Reduction policies, Communication from the Commission to the European Parliament, the European Council, the Council, the European Economic and Social Committee and the Committee of the Regions; COM(2013) 479 Final; European Commission: Brussels, Belgium, 2013.

10. Bouman, E.A.; Lindstad, E.; Rialland, A.I.; Strømman, A.H. State-of-the-art technologies, measures, and potential for reducing GHG emissions from shipping-A review. Transp. Res. Part D Transp. Environ. 2017, 52, 408-421. [CrossRef]

11. Xing, H.; Spence, S.; Chen, H. A comprehensive review on countermeasures for $\mathrm{CO}_{2}$ emissions from ships. Renew. Sustain. Energy Rev. 2020, 134, 110222. [CrossRef]

12. Halim, R.A.; Kirstein, L.; Merk, O.; Martinez, L.M. Decarbonisation pathways for international maritime transport: A model-based policy impact assessment. Sustainability 2018, 10, 2243. [CrossRef]

13. Ren, H.; Ding, Y.; Sui, C. Influence of EEDI (Energy Efficiency Design Index) on ship-engine-propeller matching. J. Mar. Sci. Eng. 2019, 7, 425. [CrossRef]

14. Faber, J.; Nelissen, D.; Hon, G.; Wang, H.; Tsimplis, M. Regulated Slow Steaming in Maritime Transport; An assessment of Options, Costs and Benefits: 2012. Available online: https:/ / cedelft.eu/publications/regulated-slow-steaming-in-maritime-transport/ (accessed on 11 August 2021).

15. Miola, A.; Ciuffo, B. Estimating air emissions from ships: Meta-analysis of modelling approaches and available data sources. Atmos. Environ. 2011, 45, 2242-2251. [CrossRef]

16. Wik, C.; Niemi, S. Low emission engine technologies for future tier 3 legislations-options and case studies. J. Shipp. Trade 2016, 1, 1-22. [CrossRef]

17. Lindstad, E.; Eskeland, G.S.; Rialland, A.; Valland, A. Decarbonizing Maritime Transport: The Importance of Engine Technology and Regulations for LNG to Serve as a Transition Fuel. Sustainability 2020, 12, 8793. [CrossRef]

18. De Marco, A.; Mancini, S.; Pensa, C.; Calise, G.; De Luca, F. Flettner Rotor Concept for Marine Applications: A Systematic Study. Int. J. Rotating Mach. 2016, 2016, 1-12. [CrossRef]

19. Chou, T.; Kosmas, V.; Acciaro, M.; Renken, K. A Comeback of Wind Power in Shipping: An Economic and Operational Re-view on the Wind-Assisted Ship Propulsion Technology. Sustainability 2021, 13, 1880. [CrossRef]

20. Prussi, M.; Scarlat, N.; Acciaro, M.; Kosmas, V. Potential and limiting factors in the use of alternative fuels in the European maritime sector. J. Clean. Prod. 2021, 291, 125849. [CrossRef]

21. Al-Aboosi, F.Y.; El-Halwagi, M.M.; Moore, M.; Nielsen, R.B. Renewable ammonia as an alternative fuel for the shipping industry. Curr. Opin. Chem. Eng. 2021, 31, 100670. [CrossRef]

22. Chiaramonti, D.; Talluri, G.; Scarlat, N.; Prussi, M. The challenge of forecasting the role of biofuel in EU transport decarbonisation at 2050: A meta-analysis review of published scenarios. Renew. Sustain. Energy Rev. 2021, 139, 110715. [CrossRef]

23. Psaraftis, H.N. Speed optimization vs speed reduction: The choice between speed limits and a Bunker Levy. Sustainability 2019, 11, 2249. Available online: https://www.mdpi.com/article/10.3390/su131810447/sustainability (accessed on 1 April 2021). [CrossRef]

24. Faber, J.; Huigen, T.; Nelissen, D. Regulating speed: A Short-term Measure to Reduce Maritime GHG Emissions; CE Delft Publication: Delft, The Netherlands, 2017; Available online: www.cedelft.eu (accessed on 25 February 2021).

25. Frontier Economics. Reducing the UK Maritime Sector's Contribution to Climate Change and Air Pollution; Frontier Economics: London, UK, 2019.

26. Lagouvardou, S.; Psaraftis, H.N.; Zis, T. A literature survey on market-based measures for the decarbonization of shipping. Sustainability 2020, 12, 3953. [CrossRef]

27. Carbon Offsetting and Reduction Scheme for International Aviation (CORSIA). Available online: https://www.icao.int/ environmental-protection/CORSIA/Pages/default.aspx (accessed on 1 April 2021).

28. European Commission. Directive to Enhance Cost-Effective Emission Reductions and Low-Carbon Investments; Directive (EU) 2018/410; European Commission: Brussels, Belgium, 2018.

29. European Commission. Regulation (EU) 2015/757 of the European Parliament and the Council of 29 April 2015 on the Monitoring, Reporting and Verification of Carbon Dioxide Emissions from Maritime Transport, and Amending; Directive 2009/16/EC; European Commission: Brussels, Belgium, 2015.

30. THETIS-MRV. Available online: https://mrv.emsa.europa.eu/\#public/emission-report (accessed on 1 April 2021). 
31. Panagakos, G.; Pessôa, T.D.S.; Dessypris, N.; Barfod, M.B.; Psaraftis, H.N. Monitoring the carbon footprint of dry bulk shipping in the EU: An early assessment of the MRV regulation. Sustainability 2019, 11, 5133. [CrossRef]

32. European Commission. Strategic Transport Research and Innovation Agenda (STRIA). In Towards Clean, Competitive and Connected Mobility: The Contribution of Transport Research and Innovation to the Mobility Package; Staff Working Document; SWD(2017)223 Final; European Commission: Brussels, Belgium, 2017.

33. Tsakalidis, A.; van Balen, M.; Gkoumas, K.; Pekar, F. Catalyzing sustainable transport innovation through policy support and monitoring: The case of TRIMIS and the European green deal. Sustainability 2020, 12, 3171. [CrossRef]

34. Tsakalidis, A.; Gkoumas, K.; Grosso, M.; Pekár, F. TRIMIS: Modular Development of an Integrated Policy-Support Tool for Forward-Oriented Transport Research and Innovation Analysis. Sustainability 2020, 12, 10194. [CrossRef]

35. Grosso, M.; Marques Dos Santos, F.; Gkoumas, K.; Ortega Hortelano, A.; Stepniak, M.; Tsakalidis, A.; Pekar, F. Waterborne transport in Europe-The role of Research and Innovation in Decarbonization; EUR 30636 EN; Publications Office of the European Union: Luxembourg, 2021.

36. Wan, Z.; El Makhloufi, A.; Chen, Y.; Tang, J. Decarbonizing the international shipping industry: Solutions and policy recommendations. Mar. Pollut. Bull. 2018, 126, 428-435. [CrossRef]

37. Balcombe, P.; Brierley, J.; Lewis, C.; Skatvedt, L.; Speirs, J.; Hawkes, A.; Staffell, I. How to decarbonise international shipping: Options for fuels, technologies and policies. Energy Convers. Manag. 2019, 182, 72-88. [CrossRef]

38. Rehurek, R.; Sojka, P. Software Framework for Topic modelling with Large Corpora. In Proceedings of the LREC 2010 Workshop on New Challenges for NLP Frameworks. 2010. Available online: http:/ / citeseerx.ist.psu.edu/viewdoc/summary?doi=10.1.1.6 95.4595 (accessed on 17 September 2021).

39. Mihalcea, R.; Tarau, P. Textrank: Bringing Order into Text. In Proceedings of the 2004 Conference on Empirical Methods in Natural Language Processing. 2004. Available online: https:/ / aclanthology.org/W04-3252.pdf (accessed on 17 September 2021).

40. Scopus. 2020. Available online: www.scopus.com (accessed on 1 April 2021).

41. Gkoumas, K.; Tsakalidis, A. A framework for the taxonomy and assessment of new and emerging transport technologies and trends. Transport 2019, 34, 455-466. [CrossRef]

42. Héder, M. From NASA to EU: The evolution of the TRL scale in Public Section Innovation. Innov. J. Public Sect. Innov. J. 2017, 22, 3.

43. De Castro, C.; Carpintero, Ó.; Frechoso, F.; Mediavilla, M.; de Miguel, L.J. A top-down approach to assess physical and ecological limits of biofuels. Energy 2014, 64, 506-512. [CrossRef]

44. Waterborne Technology Platform. 2020. Available online: https://www.waterborne.eu/images/documents/201021_SRIA_Zero_ Emission_Waterborne_Transport_spread.pdf (accessed on 1 April 2021). 